\title{
Studi Analisis Prestasi Atlet Karate PPLP Dispora Provinsi Sulawesi Selatan
}

\author{
Hamdan. H \\ Institut Agama Islam DDI Polewali Mandar \\ Jl. Gatot Soebroto Kelurahan Madatte Kecamatan Polewali Kab. Polewali Mandar
}

\begin{abstract}
ABSTRAK
Penelitian ini bertujuan untuk mengetahui, bagaimana gambaran peningkatan pembinaan prestasi olahraga karate pplp DISPORA Sulawesi Selatan. Penelitian ini menggunakan metode pendekatan kualitatif, metode survei, dengan sampel dan populasi seluruh atlet karate PPLP DISPORA Sulawesi Selatan, perwakilan pihak DISPORA, pelatih serta unsure lain yang berhubungan dengan karate pplp DISPORA Sulawesi Selatan.

Hasil penelitian menunjukkan gambaran peningkatan pembinaan prestasi atlet karate pplp DISPORA Sulawesi selatan sudah dilakukan sesuai dengan standar pada umumnya seperti pemilihan pelatih yang di berikan oleh DISPORA Sulawesi Selatan, pelatih yang telah dipilih oleh DISPORA kemudian diseleksi kembali oleh DISPORA dengan mempertimbangkan beberapa hal, yaitu pengalaman dibuktikan dengan sertifikat yang dilampirkan, kesehatan pelatih, ketermapilan dalam melatih kemudian atlet yang menjadi prioritas adalah atlet yang terbaik di antara yang terbaik setelah melalui tahapan rekrutmen. Pemilihan atlet sudah dilakukan secara tepat karena sebelum dilakukan pemilihan atau rekrutmen atlet sudah ada indikator sebagai parameter atlet yang bisa masuk dalam program atlet pplp DISPORA Sulawesi Selatan. Program latihan di perlukan waktu yang cukup lama serta penyusunan program latihan yang seksama, teratur, sistematis, bertahap serta terus menerus sepanjang tahun tanpa selingan berhenti sedikitpun. Jika dilihat dari lamanya sentralisasi, maka kita tidak bisa menyangka prestasi pada kejurnas PPLP 2018 mengalami peningkatan dibandingkan dengan kejurnas PPLP 2017 yang lama sentralisasi latihannya jauh lebih singkat. Dalam pembuatan program latihan waktu pertandingan sangatlah penting untuk diketahui. Sebab waktu pertandingan merupakan kunci dan puncaknya dari seluruh program latihan yang di susun. Kondisi fisik atlet ditemukan bahwa ada atlet yang diharapkan dapat memperoleh medali pada kejurnas PPLP 2017 sedang tidak dalam kondisi fisik yang memungkinkan untuk memaksimalkan penampilannya dalam pertandingan. Kondisi mental atlet. Aspek psikologis dapat sangat mempengaruhi performa atlet dilapangan. Dimana kondisi psikologis atlet dapat menjadi penunjang bahkan penghambat dan menganggu penampilan atau Kondisi pertandingan.
\end{abstract}

Kata Kunci: Prestasi, Program Latihan dan Mental

\section{ABSTRACT}

The study aims at discovering the description of coaching improvement of the achievement of karate athletes of PPLP DISPORA in South Sulawesi. The study employed qualitative approach method and survey method. The population and the sample of the study were all Karate athletes of PPLP DISPORA in South Sulawesi, the representative of DISPORA, coaches, and other elements related to Karate of PPLP DISPORA in South Sulawesi.

The results of the study reveal that the description of coaching improvement of the achievement of karate athletes of PPLP DISPORA in South Sulawesi had been conducted in 
accordance with general standards of trainer selection given by DISPORA in South Sulawesi. The chosen traibers by by DISPORA were then selected again by DISPORA by considering several components, namely experience proven with certificates attached, trainer's health, training skills. The selection of athletes who become priorities is the best among the best athlete after going through the recruitment stage. The selection of athletes had been done appropriately because before the selection or recruitment of athletes there were already indicators as parameters of athletes that can be included in PPLP DISPORA in South Sulawesi. The training program needed longer time and trining preparation program which was thorough, regular, systematic, gradual, and sustainable throughout the year without the slightest interruption. If people looked at the length of centralization, they could not expect that the achievement of the PPLP 2018 National championship improved compared to the PPLP National championship 2017 which had a much shorter centralization of training. In making the training program, the time of the mach is very important to know because it is the key and the peak of all the training programs compiled. The athlete's physical condition was discovered that there were athletes who were expected to get a medal at the 2017 PPLP National championship while not in a physical condition that allowed them to maximize their appearance in the match. In terms of mental condition of athletes, the psychology aspect can greatly affect the performance of athletes on the field where the psychological condition of athletes can be a support even inhibitors and interfere the appearance or condition of the match.

Keywords: Achievement, Training Program, Mental

\section{PENDAHULUAN}

Seiring dengan perkembangan olahraga yang begitu pesat di dunia termasuk di Indonesia, olahraga merupakan upaya salah satu usaha untuk mengharumkan nama bangsa dan Negara. Oleh karena itu, pendidikan dan pembinaan olahraga harus terus di tingkatkan sesuai dengan tujuan pendidikan olahraga yaitu pembinaan dan peningkatan pengembangan olahraga diarahkan kepada terbentuknya manusia yang siap fisik dan mental serta berprestasi. Sebab keberhasilan suatu bangsa di dalam pembangunan tergantung pula pada kesanggupan fisik dan mental manusianya.

Pusat Pendidikan Latihan dan Olahraga Pelajar (PPLP) Sulawesi Selatan adalah wadah untuk menghimpun serta membina atlet dengan minat dan bakat olahraga yang tinggi. Atlet-atlet binaan PPLP akan di kembangkan agar potensinya makin terasa, hal ini memerlukan sebuah proses dengan mengundang berbagai tolak ukur sehingga calonatlet yang masuk dan di terima sebagai atle pelajar di PPLP Sulawesi Selatan merupakan atlet yang di hasilkan dari kompetensi dan seleksi yang ketat serta terencana, terukur dan berkelanjutan.

Salah satu cabang yang menjadi binaan di PPLP Sulawesi Selatan yaitu cabang Olahraga Karate, karate merupakan salahsatu cabang yang sangat di unggulkan di Sulawesi Selatan terbukti dengan berkiprah di kancah Internasioanal dan merupakan salah satu lumbung atlet Nasional hingga sekarang. Sama halnya dengan provinsi lain di Indonesia, atlet karate pplp dispora Sulawesi dalam pelaksanaan sampai dengan sekarang telah melaksanakan pembinaan atlet pelajar potensi berprestasi yaitu cabor karate, setiap tahun selalu mengikuti perhelatan bergengsi kejurnas PPLP yang dilaksanakan setiap setahun sekali. Salah satu cabang olahraga yang diunggulkan di Sulawasi Selatan adalah cabang olahraga karate. Karate selalu menyumbangkan medali dalam setiap kejurnas PPLP baik itu medali emas, perak, perunggu. 
Fokus masalah pada penelitian ini adalah Olahraga dalam suatu daerah tentu dipengaruhi oleh banyak faktor, baik itu faktor internal (dari dalam) maupun eksternal (dari luar). Untuk itu berdasarkan uraian masalah di atas, maka rumusan masalah yang akan diteliti dalam penelitian ini adalah 1) Apa yang menjadi penyebab menurunnya prastasi atlet karate pada kejurnas PPLP 2017 ? 2) Apa yang menjadi penyebab meningkatnya prestasi atlet karate pada kejurnas PPLP 2018 di Aceh?

Dengan dilakukannya penelitian ini diharapkan agar hasil penelitian ini memiliki manfaat baik untuk peneliti sendiri maupun untuk orang lain. Manfaat yang ditemukan bisa saja bersifat teoritis dan bisa bersifat praktis. Secara teoritis penelitian ini diharapkan mampu menjadi salah satu penelitian yang dapat mengembangkan ilmu pengetahuan khususnya mengenai hal-hal yang mempengaruhi baik tidaknya prestasi dan penampilan atlet di lapangan dan dan secara praktis dapat digunakan untuk menemukan solusi dari berbagai masalah yang ditemukan pada atlet dan pelatih bahkan maneger atlet itu sendiri khususnya di lingkungan atlet karate PPLP DISPORA provinsi Sulawasi-Selatan.

\section{KAJIAN PUSTAKA}

\section{A. Konsep Prestasi Olahraga}

Setiap prestasi patut layak dibanggakan oleh setiap orang, apalagi bila prestasi yang didapat memang benar-benar sesuai dengan pengorbanan untuk mendapatkannya. Ada kepuasan yang mendalam dari jiwa atlet, pelatih maupun pengurus, jika prestasi yang ditorehkan atletnya memalui perjuangan yang panjang dan mendebarkan. Bahkan sering ditemui, pejabat atau pengurus teras top organisasi daerah dan cabang olahraga, yang menonton pertandingan, secara langsung memberikan bonus kepada atlet yang juara.

\section{B. Pembinaan Prestasi Olahraga}

Utnuk mencapai prestasi yang maksimal diperlukan pembnaan yang terprogram, terarah dan berkesinambungan serta didukung dengan penunjang yang memadai. Dan untuk mencapai prestasi optimal atlet, juga diperlukan latihan intensif dan berkesinambungan, akan tetapi dalam proses tersebut kadang-kadang akan timbul rasa bosan. Hal ini dapat menjadi penyebab penuruan prestasi, oleh karena itu diperlukan pencegahan yaitu dengan merencakan dan melakukan latihan-latihan yang bervariasi.

\section{Faktor Pendukung Prestasi}

Untuk mencapai prestasi merupakan usaha yang multikomples yang melibatakan banyak faktor baik internal maupun eksternal, kulitas latihan merupakan penopang utama tercapainya prestasi olahraga, sedangkan kualitas latihan itu sendiri ditopang oleh faktor internal yakni kemampuan atlet (bakat dan motivasi) serta faktor eksternal menurut Djoko Petik Irianto dalam Rahmat Tri Koncoro (2011: 11).

Faktor internal merupakan pendukung utama tercapainya prestasi atlet, sebab faktor ini memberikan dorongan yang lebih stabil dan kuat yang muncul dari dalam diri atlet itu sendiri, yang meliputi:

\section{Bakat}


Bakat merupakan potensi yang dibawa seseorang sejak lahir. Bakat ini merupakan faktor gen yang dimiliki oleh seseorang.

\section{Motivasi}

Motivasi disini diartikan sebagai proses yang menggerakkan seseorang hingga berbuat sesuatu. Atkinson dalam Husdarta (2011: 32 - 33), mengatakan bahwa "The term motivation refers to the arousal of tendecy to act to produce one or more effects". Istilah motivasi mengacu pada gairah kecenderungan untuk bertindak yang mengahasilkan satu atau lebih dari satu efek. Motivasi menunjukkan dorongan atau usaha untuk memenuhi atau memuaskan suatu kebutuhan atau untuk mencapai suatu tujuan.

Faktor eksternal merupakan penguat yang berpengaruh terhadap kualiatas latihan yang selanjutnya akan mempengaruhi prestasi. Faktor tersebut adalah pelatih. Melatih hampir sama dengan mengajar. Melatih dan mengajar sama - sama harus menyusun program, melaksanakan program, memeberikan bimbingan dan rorongan untuk memperoleh hasil yang lebih baik, serta melakukan penilaian dengan hasil yang diperoleh.

Dikatakan oleh Sukayanto dalam Apta Mylsidayu \& Febi Kurniawan (2015: 10), bahwa pelatih adalah seseorang yang memiliki kemampuan profesional untuk membantu mengungkapkan potensi atlet menjadi kemampuann yang nyata secara optimal dalam waktu yang relatif singkat. Pelatih adalah seorang manusia yang emiliki pekerjaan sebagai perangsang (simulator) untuk mengoptimalkan kemampuan aktifitas gerak atlet yang di kembangakan dan ditingkatkan melalui berbagai metode latihan yang disesuaikan dengan kondisi internal dan eksternal individu pelakunya.

\section{Karate}

Karate berasal dari dua suku kata yaitu "kara" yang berarti tangan dan "te" yang berarti kosong. Dimana dari arti kata tersebut maka karate dapat diartikan sebagai tangan kosong, yaitu beladiri yang hanya menggunakan bagian-bagian tubuh sebagai senjata. Menurut Ivan Yuliawan (2012: 13) karate berasal dari pengucapan dalam bahasa Okinawa "kara" berarti Cina dan "te" yang berarti tangan. Arti dari dua pengucapan tersebut adalah 'tangan Cina', 'teknik Cina', atau 'tinju Cina'. Pada dasarnya karate bertujuan untuk membuat seseorang menjadi mandiri, dapat mengatasi kesulitan tanpa bantuan orang lain, hal itu pasti dapat tercapai seandainya orang itu dapat memiliki pemikiran yang murni. Dalam karate seorang karateka dilatih dapat memiliki pemikiran seperti bayi yang tidak panik saat ada sesuatu yang terjadi di sekitarnya. Kita akan dilatih berpikiran jernih dan mengalir seperti air.

Kihon adalah latihan dasar karate yang dilakukan dengan menggunakan pukulan, tangkisan dan tendangan dengan kuda-kuda tertentu. Latihan dasar dapat dilakukan dengan kuda-kuda tidak melangkah dari tempat semula yang disebut kihon wasa dan dapat pula dilakukan dengan bergerak maju atau mundur, menggeser kesamping kiri dan kanan, serta dapat dilakukan dengan cara bergerak ke empat arah mata angin yang disebut dengan kihon ido.

\section{Kata}

Pada perkembangannya sekarang pertandingan kata dimaikan di atas tatami (matras pertandingan) berukuran 10 × 10 meter, dengan wasit/juri terdiri dari lima orang, satu orang wasit utama dan empat orang lainnya wasit pembantu. Penilaian diberikan dengan menggunakan bendera 
yang berwarna merah dan biru sesuai dengann warna sabuk yang digunkan oleh peserta. Jika kata yang ditampilkan oleh satu peserta dianggap bagus oleh wasit/juri maka wasit/juri dapat mengangkat bendera sesuai dengan warna sabuk peserta yang dinilainya memberikan penampilan terbaik. Karateka yang mendapat jumlah bendera paling banyak adalah pemenang dari pertandingan tersebut. Penilaian ditunjukkan pada pelaksanaan yang baik, cermat, jelas, penuh kesungguhan dan semangat. Demikian pula harus dilihat irama dan dinamika yang mencerminkan kecepatan, keharmonisan, kelenturan tubuh dan lain-lain.

\section{Kumite}

Latihan kumite merupakan aplikasi kihon dalam wujud latihan memukul, menendang dan menangkis seranagan lawan. Jenis-jenis latihan kumite dapat dibagi atas beberapa metode atau variasi yaitu; latihan yang diatur dahulu (yaukuzoku kumite), dan latihan bebas (jiyu kumite). Latihan yaukuzoku kumite dapat dilakukan dengan latihan kihon kumite, gohon kumite dan ippon kumite.

\section{E. Kerangka Pikir}

Pengenalan dan pemahaman tentang prestasi olahraga sangatlah penting, terutama prestasi karate PPLP DISPORA Sulawesi Selatan. Karate dalam perkembangannya saat ini merupakan olahraga prestasi yang memiliki kompetitif yang tinggi, sehingga bagi atlet sendiri dituntut untuk berlatih lebih keras agar dapat mencapai performaance yang terbaik dalam penampilannya di setiap pertandingan yang diikuti. Untuk itu dukungan dari semua pihak sangat diperlukan terutama pemerintah daerah yang menyediakan semua fasilitas bagi atlet dalam proses latihan untuk mencapai prestasi optimal. Pengelolaan pembinaan merupakan proses yang sangat diperhatikan dalam penjaringan atlet yang akan di bina dengan serius dan bertujuan untuk meningkatkan prestasi yang optimal dalam olahraga. Dengan menerapkan pembinaan berjenjang, mulai sejak usia dini, pra remaja, remaja hingga dewasa, diharapkan akan memunculkan bibit-bibit atlet yang handal untuk bisa mencapai prestasi optimal. Untuk itu perlu manajemen pembinaan yang tertata dengan baik secara kontinyu, bertahap dan berkelanjutan serta didukung juga oleh tenaga profesional yang memiliki dedikasi tinggi terhadap peningkata prestasi karate dan juga pelatih yang berkualitas untuk menerapkan program latihan yang tepat dalam proses pembinaan. Untuk menciptaan banyak atletatlet yang berprestasi membutuhkan waktu yang cukup lama dan harus dilakukan secara kontinyu, maka Provinsi Sulawesi Selatan harus mempunyai pembinaan prestasi yang bagus.

\section{METODE PENELITIAN}

Menurut Sukardi (2014: 3) penelitian diartikan sebagai cara pengamatan yang inkuiri dan mempunyai tujuan untuk mencari jawaban permasalahan atauproses penemuan, baik itu discovery maupun invention. Dalam sebuah penelitian ada tahap - tahap yang harus dilakukan. Sesuatu bisa saja dikatakan tidak benar jika metode yang digunakan tidak jelas, kabur, atau sekenanya saja. Untuk dapat melakukan suatu penelitian yang baik diperlukan dengan apayang kita kenal sebagai metodologi penelitian. 
Secara harfiah metodologi penelitian diartikan sebagai sekumpulan peraturan, kegiatan, dan prosedur yang digunakan oleh pelaku suatu disiplin ilmu untuk melakukan suatu penelitian menurutTatang Ary Gumanti dkk, (2016: 6). Untuk memperoleh hasil penelitian yang baik dalam penelitian ini maka metode yang digunakan adalah pendekatan kuliatatif dengan desain deskriftif. Menurut Setyosari dalam Dano Eko Agustinova (2015: 9) penelitian kualitatif adalah penelitian yang menggunakan metode observasi, wawancara, analisis isi, dan metode pengumpulan data lainnya untuk menyajikan respon - respon dari perilaku subjek. Creswell dalam RhchiatiWiriaadmadja (2012: 8) menjabarkan, bahwa penelitian kualitatif adalah sebuah proses inkuiri yang menyelidiki masalah sosial dan kemanuasiaan dengan tradisi metodologi yang berbeda.

Penelitian ini dilaksanakan dengan cara mewawancarai beberapa informan yang dianggap penting, sehingga lokasi tempat untuk melaksakan penelitian tidak dapat ditetapkan secara pasti. Tempat wawacara dilaksanakan diharapkan mampu membuat informan merasa nyaman dan dapat memberikan informasi yang diharapkan sesuai dengan fokus penelitian yang dilakukan. Akan tetapi kemungkinan besar wawancara dan interviu pelatih dan atlet bertempat di tempat latihan atlet karate (Dojo Gor Sudiang) PPLP SUL-SEL.

\section{HASIL PENELITIAN DAN PEMBAHASAN}

\section{A. Penyebab Penurunan Prestasi Atlet dalam Kejurnas PPLP 2017}

Ada beberapa hal yang kami temukan dalam penelitian yang menunjukkan suatu penyebab penurunan prestasi yang dialami oleh cabang olahraga karate atlet dalam kejurnas PPLP 2017, diantaranya adalah:

1. Pemilihan Pelatih

Pada kejurnas PPLP 2017 yang di adakan di padang, pemilihan pelatih dilakukan sesuai dengan standar pemilihan pelatih yang di berikan oleh DISPORA Sulawesi Selatan, pelatih yang telah dipilih oleh DISPORA kemudian diseleksi kembali oleh DISPORA dengan mempertimbangkan beberapa hal, yaitu pengalaman dibuktikan dengan sertifikat yang dilampirkan, kesehatan pelatih, ketermapilan dalam melatih.

Dibalik pemilihan dan verifikasi yang telah dilaksakan oleh DISPORA itu sendiri. Pemilihan pelatih dipandang oleh pelatih yang terpili pada tahun 2017 dilakukan menjelang 3 bulan sebelum pertandingan kejurnas PPLP 2017 di padang. jadi bagi kami sebagai pelatih mau tak mau harus di tuntut untuk memproses atlet yang kami tangani untuk di matangkan supaya siap berkompetisi dalam waktu 3 bulan.

\section{Pemilihan Atlet}

Dalam proses wawancara ditemukan bahwa sebagian besar atlet yang terpilih masuk kedalam tim kejurnas PPLP 2017 adalah atlet-atlet yang namanya sudah melalui tahapan tahapan rekrukment. Pemilihan atlet karate pada waktu kejurnas PPLP 2017 di padang, sudah sesuai dengan indikator dalam pedoman Program DISPORA, dimana yang menjadi prioritas adalah atlet yang terbaik di 
antara yang terbaik setelah melalui tahapan rekrukment. Pemilihan atlet sudah dilakukan secara tepat karena sebelum dilakukan pemilihan atau rekrutmen atlet sudah ada indikator sebagai parameter atlet yang bisa masuk dalam program atlet PPLP DISPORA Sulsel. Dan memang pelatih sudah mempunyai rekomendasi dilihat dari tahapan dan hasil seleksi sehingga pihak DISPORA memilih atlet yang terbaik di antara yang terbaik.

Pada pemilihan atlet kali ini untuk mengikuti kejurnas PPLP 2017, dimana ada beberapa atlet yang terpilih masi minim pengalaman dan notabene atlet baru dan belum jadi secara fisik, teknik, taktik, dan mental atlet dan perekrutan atlet juga 3 bulan sebelum pertandingan jadi secara tidak langsung atlet tersebut belum matang dan belum siap untuk berkompetisi di karenakan jadwal latihan yang singkat dan tidak sesuai program yang telah di tetapkan oleh DISPORA.

\section{Program Latihan}

Mempersiapkan seorang atlet untuk mengahadapi pertandingan hingga mencapai tingkat prestasi yang tinggi atau maksimal, di perlukan waktu yang cukup lama serta penyusunan program latihan yang seksama, teratur, sistematis, bertahap serta terus menerus sepanjang tahun tanpa selingan berhenti sedikitpun. Jika dilihat dari lamanya sentralisasi, maka kita tidak bisa menyangka prestasi pada kejurnas PPLP 2018 mengalami peningkatan dibandingkan dengan kejurnas PPLP 2017 yang lama sentralisasi latihannya jauh lebih singkat. Dalam pembuatan program latihan waktu pertandingan sangatlah penting untuk diketahui. Sebab waktu pertandingan merupakan kunci dan puncaknya dari seluruh program latihan yang disusun. Dalam proses wawancara ditemukan bahwa ada kendala yang didapatkan oleh para pelatih untuk persiapan kejurnas PPLP 2017 Di karenakan waktu untuk program sangat sedikit karna menjelang 3 bulan sebelum pertandingan jadi pada umumnya seperti tahap umum, tahap khusus, pra kompetisi, dan kompetisi dalam perjanan itu pelatih menyiapkan secara jangka pendek latihan fisik dasar pembentukan karna pelatih secara singkat mempersiapkan bentuk di persiapan umum karna atlet pplp yang baru di terimah merupakan atlet dari daerah yang notabene latihan yang dia dapatkan didaerah nya kurang lengkap kebanyakan saya menghabiskan di tahapan umum nanti saya masuk ke tahap khusus untuk mematangkan teknik. Jadi semua tidak berjalan dengan lanjcar dan tidak sesuai dengan program latihan yang pelatih buat untuk jangka panjang.

\section{Kondisi Fisik Atlet}

Kondisi fisik atlet adalah salah satu faktor penentu bagaimana penampilan atlet dilapangan. Hal ini harus diperhatikan betul oleh para pelatih. Dikarenakan, jika kondisi fisik atlet menurun maka saat latihan mereka tidak akan maksimal. Bahkan jika dipaksakan itu akan berdampak buruk pada atlet itu sendiri.

Dalam hasil wawancara dengan para pelatih dan atlet ditemukan bahwa ada atlet yang diharapkan dapat memperoleh medali pada kejurnas PPLP 2017 sedang tidak dalam kondisi fisik yang memungkinkan untuk memaksimalkan penampilannya dalam pertandingan.

Kesehatan olahraga merupakan landasan bagi kinerja atlet dalam berolahraga secara maksimal. Pemahaman dan penerapan pengetahuan tentang ilmu kesetahan olahraga dapat mendorong para pelaku, Pembina, dan pelatih olahraga untuk bertindak dan berbuat secara ilmiah 
dan akurat, tidak dengan melakukan pemikiran atau terkaan dalam menyusun dan mengondisikan program latihan. Salah satu penyebab turunnya daya tahan fisik atlet yang menyebabkan timbulnya peyakit maka dengan latihan yang berat itu dapat membuat kondisi tubuh menurun bahkan sampai sakit.

Di karenakan waktu latihan yang singkat dalam persiapan sebuah kompetisi pelatih di tuntut untuk membuat intensitas latihan yang tinggi untuk nisa memantapkan kondisi fisik atlet tersebut dalam waktu singkat. dalam wawancara tersebut atlet mengatakan latihan persiapan kejurnas PPLP 2017 itu intensitas latihan fisik sangat tinggi sampai sampai kebanyakan atlet mengalami mata berkunang kunang, kepala pusing, dan ada pula yang sampai muntah mereka mengatakan fisik kami sangat di gembleng pada waktu itu. Menurut harsono (1998), mengemukakan kembali bahwa, "saat - saat paling berbahaya dalam latihan, biasanya adalah pada tiga atau empat minggu pertama dan musim latihan, karena biasanya saat itu atlet belum memiliki kekuatan, kelentukan, daya tahan, dan keterampilan yang cukup. Dia juga belum cukup lincah untuk melakukan gerakan - gerakan, sehingga kekakuan gerakan sering dapat menyebabkan cedera otot dan sendi. Ini berarti bahwa kondisi fisiknya masih jauh dibawah kondisi fisik yang di perlukan untuk suatu latihan yang berat atau pertandingan."

\section{Kondisi Mental Atlet}

Data dalam penetian ini diperoleh bukan hanya pada hasil wawancara akan tetapi diperoleh juga dari beberapa hasil dokumentasi yang berupa laporan hasil pertandingan pada kejurnas PPLP 2017 di padang. Baik dalam wawancara maupun dokumentasi ditemukan bahwa ada beberapa atlet yang kurang siap dalam menghadapi kompesiti di Padang. Hal - hal yang menyebabkan ketidak siapan dari para atlet tersebut adalah:

a. Kesadaran diri akan kurang maksimalnya latihan yang dilakukan oleh dirinya pribadi.

b. Menurunnya semangat juang, dikarenakan mengetahui bahwa lawan tanding mereka adalah atlet - atlet nasional yang memiliki kemampuan di atas dirinya.

Seorang manusia tidak bisa terpisahkan dari fisik dan psikologis. Yang satu dengan yang alinnya tidak dapat dipisahkan. Ketegangan atau stress yang dirasakan oleh satu bagian akan dirasakan pula oleh bagian yang lain. Kita tidak dapat menghindar dari pengaruh emosi. Pada dikatakan setiap atlet menginginkan hasil prestasi baik berdasarkan kemampuannya. Aspek psikologis dapat sangat mempengaruhi performa atlet dilapang. Dimana kondisi psikologis atlet dapat menjadi penunjang atau bahkan penghambat atau menganggu penampilan atau prestasi.

Menurut Husdarta (2011: 80) salah satu aspek psikologis yang mengganngu penampilan atlet yaitu ketegangan/kecemasan. Ketegangan atau yang biasa lebih dikenal dengan stress yaitu tekanan atau sesuatu yang terasa menekan dari dalam diri seseorang. Sumber ketegangan bisa berasal dari dalam diri atlet, dan bisa juga dari luar. Ketegangan yang berasal dari dalam dirinya, misalnya perasaan takut, ragu-ragu akan kemampuannya, perasaan kurang latihan, dan sebagainya.

Apa yang dialami oleh beberapa atlet yang dipersiapkan untuk mengikuti kejurnas PPLP 2017 adalah kecemasan yang berasal dari dalam dirinya sendiri dan menyebabkan turunnya performa mereka di pertandingan. Dapat dikatakan bahwa data tersebut sesuai dengan klasifiasi yang 
dikemukakan Husdarta (2011: 81), yang mengatakan kecemasan dan ketakutan atlet pada umumnya dapat di klarifikasikan dalam beberapa kategori:
a. Takut kalau gagal dalam pertandingan
b. Takut akan akibat sosial dan kualitas prestasinya
c. Takut cedera atau hal lain yang menimpa dirinya
d. Takut terhadap agrasi fisik baik oleh lawan aupun dirinya.
e. Takut bahwa kondisi fisiknya tidak akan mampu menyelesaikan tugasnya atau pertandingannya dengan baik.

\section{Kondisi pertandingan}

Bisa dikatakan bahwa kondisi pertandingan juga berpengaruh dalam prestasi atlet. Kondisipertandingan pada kejurnas PPLP 2017 sama dengan pertnadingan - pertandingan kejurnas PPLP yang sebelumnya di daerah lain. Dari pihak DISPORA menyatakan bahwa kondisi dan situasi atlet di padang cukup bagus sesuai ketentuan pertandingan namun secara mental terganggu juga dengan perlengkapan pertandingan, yang tidak sesuai dengan kebutuhan atlet.

Terdapat juga kendala yang dialami oleh pelatih saat pertandingan di kejurnas PPLP 2017 berlangsung. Dimana para pelatih mengatakan Kendalanya di komunikasi karna kita tahu pertandingan karate itu selalu di tempatkan di Gor indoor apalagi kejurnas PPLP sdh diikuti 29 provinsi jadi saya sebagai pelatih kewalahan kesimpulannya kendala nya di teknis pada saat di tempat pertandingan. dengan matras pertandingan yang ada empat buah, menyulitkan para pelatih untuk memperhatihan satu persatu atlet di lapangan pertandingan. Atlet yang baru pertama dan dengan pengalaman tanding yang sedikit merasak kurang diperhatihan oleh pelatih di tempat pertandingan.

Tempat pertandingan yang diadakan di padang juga disebut-sebut olah pelatih adalah bukan merupakan tempat yang nyaman untuk dilangsungkannya sebuah pertandingan karate. Dalam wawancaranya pelatih mengatakan bahwa di padang waktu pertandingan kejurnas PPLP 2017 berlangsung khususnya pada partai final ada atlet yang hamper dijanggal kemenangannya. Tapi syukur atlet tersebut berhasil mendapatkan 1 emas, adapun faktor nonteknis di lapangan pertandingan. Besarnya gengsi padang sebagai tuan rumah pertandingan membuat parawasit lebih memilih untuk memenangkan tuah rumah pertandingan. Buktinya sampai sekarang juara mereka yang berhasil juara pada saat itu tidak bisa berprestasi di event yang lain dan tidak pernah menunjukkan prestasi kembali. Menurut Lhaksana (2011), factor psikis merupakan kunci dari keberhasilan dan kesuksesan seseorang atlet atau sebuah tim. Atlet harus memiliki psikis yang stabil dan dapat mengalahkan segala tekanan non-teknis, seperti halnya atmosfer pertandingan, penonton atau supporter dan beban yang diberikan pada pengurus.

Melalui berbagai informasi yang diperoleh baik dari hasil wawancara maupun dari data laporan hasil pertandingan terakhir pada kejurnas PPLP 2017 padang memang menunjukkan berbagai macam kekurangan akan tetapi di harapakan agar semua kekurangan tersebut yang disebut dan dijelaskan di atas tidak menjadi penghalang tetapi dapat menjadi acuan dan motivasi untuk pengurus, pelatih dan atlet dalam persiapan kompetisi di kejurnas PPLP selanjutnya.

Fokus dalam penelitian ini adalah peningkatan prestasi yang di alami oleh cabang olahraga karate pada kejurnas PPLP 2017 dan kejurnas PPLP 2018 ini merupakan pengharapan yang di 
inginkan oleh pihak DISPORA sulsel dimana pada kejurnas PPLP 2017 tim karate hanya mampu meraih 1 medali emas dan 5 medali perunggu dan pada kejurnas PPLP 2018 tim karate memperoleh 1 medali emas, 2 medali perak, dan 2 medali perunggu.

\section{B. Penyebab Peningkatan Prestasi Atlet}

Berdasarkan hasil wawancara yang dilakukan peneliti dengan informan untuk mengetahui apa yang menjadi penyebab peningkatan prestasi atlet, ditemukan beberapa informasi yang bisa menjadi perbandingan dengan kejurnas PPLP 2017 dan kejurnas PPLP 2018 yang diadakan padang dan aceh. Dan ada berberapa hal yang kami temukan dalam penelitian yang menunjukkan suatu penunjang meningkatnya prestasi atlet dalam suatu pertandingan, diantaranya:

1. Manajemen Pembinaan

Manajemen pembinaan atlet PPLP DISPORA Sulawesi Selatan dimulai dengan di bentuknya pplp dispora Sulawesi selatan, tujuan dari pplp adalah Pusat Pendidikan dan Latihan Pelajar untuk mempersiakan atlet yang akan mengikuti kompetisi agar lebih siap baik dari fisik maupun mental. Atlet pplp dispora Sulawesi selatan memiliki jam latihan yang terjadwal. Hal ini sejalan dengan teori manajemen Terry dalam Harsuki (2012: 85) yang mengatakan bahwa manegemen adalah perencanaan yang pada dasarnya adalah penyusunan sebuah pola tentang aktivitas-aktivitas masa yang akan datang yang terintegrasi dan dipredeterminasi. Sama halnya dengan yang dikatakan oleh Drucker dalam Harsuki (2012: 87) bahwa pada hakikatnya perencaan adalah pemilihan saat sekarang terhadap kondisi masa depan yang dikehendaki beserta langkah-langkah yang diperlukan untuk mewujudkannya.

Dalam penelitian ini ditemukan bahwa pemilihan atlet dilakukan dengan beberapa tahap. Dalam persiapan mengikuti KEJURNAS PPLP 2018 DISPORA Sulsel membentuk Satgas. Selanjutnya Satgas ini menyusun Program pelatihan dengan membagi dalam beberapa tahapan, Tahap pemilihan atlet pada kejurnas PPLP 2017 Pemilihan atlet tentunya sesuai dengan indicator dan pedoman DISPORA yaitu di lakukan tahapan dan seleksi secara ketat dan memang pelatih sudah mempunyai rekomendasi di lihat dari tahapan dan hasil seleksi sehingga pihak kami memilih atlet yang terbaik di antara yang terbaik.

Dengan penyusunan tahap diatas dapat kita lihat bahwa pemilihan atlet memang sudah direncanakan dengan baik untk persiapan kejurnas PPLP 2017 Padang. Akan tetapi ada beberapa tahapan yang melalui permintaan pelatih berbeda dengan apa yang telah di rencanakan oleh DISPORA. Permintaan pelatih ini tidak memberikan hambatan apapun akan tetapi pelatih mempertimbangakan hal positif dari segi yang positif bagi atlet. Mengingat pelatih harus mempertimbangakan hal tebaik untuk atlet agar dapat meraih hasil terbaik dalam kompetisi yang disiapkan. Ini sesuai dengan tugas pelatih yang diungkapkan oleh Apta Mylsidayu dan Febi Kurniawan (2015: 12) yang salah satu nya adalah mengorganisir dan mengelola proses latihan.

\section{Latihan dan Program Latihan}

Dalam latihan ada dua unsur yang berperan penting didalamnya, antaranya pelatih dan juga atlet. Pelatih merupakan orang berperan untuk menyusun program latihan yang baik, melaksanakan 
program latihan yang telah dibuat, memberikan bimbingan dan dorongan untuk memperoloh hasil yang lebih baik, serta melakukan hasil penilaian tentang hasil yang diperoleh.

a. Pelatih

Pelatih pada umumnya telah melewati kiprahnya di dunia olahraga sebagai seorang atlet. Oleh karenanya ketika menjadi seorang pelatih bagi atlet - atletnya di sebuah cabang olahraga, pelatih harus menjalankan profesinya secara professional. Sensei FL, dan sensei WP dalam wawancaranya ditemukan bahwa mereka selalu menjaga kedekatan dan komunikasi terhadap para atlet karate PPLP yang mereka latih baik itu di KEJURNAS PPLP 2017 DAN KEJURNAS PPLP 2018. Mereka menyayangi atlet-atlet yang mereka latih sama seperti anak mereka sendiri, mereka saling berbicara layaknya teman yang baik, dan memberikan saran serta masukkan yang baik layaknya seorang guru akan tetapi tidak menggurui. Mereka mengenal para atlet dengan baik semenjak atlet tersebut masuk di team karate PPLP DISPORA Sulawesi Selatan, mereka memberikan dorogan untuk berlatih lebih giat agar mampu memperoleh prestasi yang baik dengan menyalurkan ilmu-ilmu yang mereka miliki secara ikhlas dan tulus. Sama halnya dengan yang di terangkan Syarif Hidayat (2014: 31) bahwa salah satu sikap pelatih adalah pelatih yang ramah dan baik hati (Nice guy coach), pelatih yang menganut paham ini mempunyai ciri sebagai berikut:

1) Selalu menggunakan pendekatan personal dan kooperatif pada anggota staf kepelatihan dan atletnya.

2) Penuh perhatian dan ramah terhadap atlet.

3) Peduli masalah yang dihadapi setiap atlet.

Seorang pelatih dalam melaksakan tugasnya perlu memiliki bahan dan informasi yang benar tentang kepelatihan agar dapat menyusun program latihan dengan baik. Untuk memimiliki itu setiap pelatih harus mengikuti berbagai macam seminar kepelatihan dan lulus bersertifikat dan berlisensi baik itu nasional apalagi dalam lingkup internasional. Pengetahuan yang diperoleh dapat memberikan pengaruh latihan yang baik dalam kematangan membuat program latihan yang baik pula yang telah mereka peroleh bukan hanya dari ilmu kepelatihan meraka tapi juga dari pengalaman mereka di lapangan yang sudah matang.

Berdasarkan hasil wawancara didapatkan bahwa pelatih tim karate PPLP untuk Sulawesi Selatan merupakan pelatih - pelatih yang memiliki ilmu kepelatihan mulai dari kota madya, provinsi, nasional, hingga inter nasional dan mereka sudah memiliki pengalaman untuk mendampingi atlet selama beberapa tahun belakangan ini. Dalam kejurnas PPLP 2017 dan kejurnas PPLP 2018 di temukan bahwa kedua pelatih diberikan waktu untuk membuat program latihan yang bukan dalam waktu yang singkat. Program latihan yang mereka buat adalah program latihan jangka panjang. Sesuai dengan apa yang dikatakan Sukadiyanto dalam Apta Mylsidayu dan Febi Kurniawan (2015: 10) bahwa pelatih adalah seseorang yang memiliki kemampuan professional untuk membantu mengungkapkan potensi atlet menjadi kemampuan yang nyata secara optimal dalam waktu yang relatif singkat.

b. Atlet 
Sama seperti yang ditemukan dalam hasil wawancara atlet yang dapat disimpulkan bahwa bagaimana pun baiknya seorang pelatih jika atletnya itu sendiri tidak menjalani latihan dengan serius maka keberhasilan tetap tidak akan bisa dia raih. Pada persiapan kejurnas PPLP 2017 dan kejurnas PPLP 2018 peneliti menemukan bahwa semangat juang dan kekeluargaan dalam tim karate PPLP DISPORA Sulawesi Selatan saat sangat besar, mereka mengerahkan seluruh tenaga dan jiwa mereka untuk latihan dan berjuang bersama di KEJURNAS PPLP tersebut.

Dengan adanya beberapa atlet yang memang merupakan atlet nasional yang meningkatkan percaya diri tim dan meningkatkan semangat juang dan sengat tanding mereka di lapangan. Dalam kondisi yang begitu bersemangat, itu mempengaruhi orang disekitarnya dimana Apta Mylsidayu dan Febi Kurniawa (2015: 59) mengatakan bahwa atlet yang memiliki momtivasi internal akan berlatih dan bertanding dengan usaha yang kerja keras dan mampu tampil lebih baik, selalu bersemangat pada saat latihan atau bertanding.

\section{Motivasi}

Motivasi merupakan dorongan meraih sesuatu yang datang dari luar maupun dari dalam diri atlet itu sendiri. Dorongan untuk meraih juara saat kejurnas PPLP 2017 dan kejurnas PPLP 2018 sangat besar. Dengan adanya beberapa pelatih mantan atlet nasional yang terpilih dalam tim karate PPLP yang dilaksanakan di padang dan di aceh yang memang dalam latihan bukan hanya saat pemusatan latihan di Sulawesi Selatan saja, mereka juga lebih banyak mendapat latihan di Pelatihan Nasional, menunjukkan kesiapan dalam menangani kompetisi dari beberapa pelatih tersebut sangat besar dan itu menyebar ke atlet yang mereka asuh. Berdasarkan data yang di peroleh dari hasil wawancara dan data hasil laporan juga menunjukkan bahwa mereka dalam konsidi siap dalam menghadapi kompetisi. Hal tersebut sejalan dengan teori yang diungkapkan oleh Husdarta dalam bukunya yang mengatakan bahwa (2011: 36), prestasi maksimal dapat dicapai oleh seorang atlet yang benar-benar telah siap untuk berkompetisi dengan segala kemapuannya.

Keluarga dan lingkungan juga merupakan sesuatu yang dapat memberikan motivasi besar dalam meraih juara. Keluarga dapat membuat seseorang bekerja keras dalam melakukan suatu hal. Beberapa atlet dalam penelitian ini mengatakan bahwa yang menjadi motivasi terbesar mereka adalah keluarga mereka. Salah satu ciri atlet yang menginternalisasi motivasi instrinsik biasanya tekun, rajin, bekerja keras, teratur, dan disiplin dalam menjalani latihan.

\section{Gizi}

Asupan gizi atlet merupakan hal yang patut di perhatikan disetiap adanya pemusatan latihan. Dalam wawancara dari berbagai sisi pandangan yang berbeda, informan dari pihak DISPORA menunjukkan bahwa perhatian gizi atlet saat sentralisasi latihan dilaksanakan di GOR SUDIANG sangat mencukupi.

Bukan hanya dari satu pihak saja, akan tetapi dari pelatih dan atlet juga merasakan hal yang sama. Pengaturan untuk makan atlet di asrama pada saat persiapan kejurnas PPLP 2017 dan kejurnas PPLP 2018 yang di adakan di padang dan aceh dikembalikan dan ditangani oleh pihak pelatih. Dana untuk makanan atlet yang diberi wewenang untuk mengatur adalah pengelolah, 
sehingga yang menangani masalah kebutuhan gizi atlet adalah pengelolah. Dimana pengelolah itu sudah memiliki pengetahuan tentang kebutuhan gizi atlet pada umumnya.

Perhatian tata gizi yang baik pada persiapan kejurnas PPLP 2017 dan kejurnas PPLP 2018 merupakan salah satu faktor pendorong teraihnya peningkatan hasil oleh para atlet pada kompetisi kejurnas PPLP. Dengan perhatian penuh mengenai asupan gizi yang diberikan kepada atlet kejurnas PPLP 2017 dan kejurnas PPLP 2018 menjadi salah satu penunjang maksimalnya proses latihan, dan maksimalnya pula penampilan atlet di lapangan pertandingan.

\section{Sarana dan Prasarana}

Semua atlet yang mengikuti pemusatan latihan untuk perisapan kejurnas PPLP 2017 dan kejurnas PPLP 2018 mengungkapkan bahwa mereka merasa cukup nyaman dengan asrama yang disediakan. Mereka menyukai suasana kekompakan dan kekeluargaan terbentuk saat pemusatan latihan. Dengan pemusatan latihan yang di tempatkan di ASRAMA ATLET PPLP dan GOR SUDIANG maka tempat latihan juga berada di lingkungan yang sama, oleh kerenanya untuk akses ketempat latihan jadi sangat mudah. Bagung tidur yang ditemui sangat berdekatan dengan tempat latihan, sehingga kuntungan untuk atlet adalah sangat mudah untuk menambah jam latihn tambahan diluar jadwal latihan yang sudah ditetapkan oleh pelatih.

Dijelaskan labih lanjut saat bincang-bincang dengan pelatih karate bahwa atlet karate itu tidak mencari mewahnya tempat istirahat saat di asrama, akan tetapi mereka mencari asrama yang akses latihan lebih dimudahkan.

6. Terbangunnya Hubungan Kekeluargaan dan Kekompakan Tim

Hubungan kekeluargaan dan kekompakan tim merupakan ikatan perasaan dua orang atau lebih, ikatan perasaan bisa terbentuk karena persamaan visi, dan misi tertentu untuk membangun hubungan kekeluargaan dan kekompakan tim karena terjalinya hubungan emosional yang baik, sehingga sering kali hubungan kekeluargaan dan kekompakan tim bisa tercapai. Dengan tercapainya hubungan kekeluargaan dan kekompakan tim, seorang atlet dan pelatih bisa meningkatkan prestasi bahkan bisa mencapai target jika terbangunya kekeluargaan dan kekompakan tim nya terjalin dengan baik. Beberapa aspek kecerdasan emosi berdasarkan (Golamen, 1997), diantaranya mengenali emosi diri, mengenali emosi, memotivasi diri, mengenali emosi orang lain, dan membina hubungan sosial.

Dalam penelitian ini ditemukan bahwa pelatih dan atlet tidak bisa berdiri sendiri, pelatih itu seperti kakak atlet itu seperti adeik, pelatih dan atlet seperti teman, dan pelatih sebagai orang tua dan atlet sebagai anak. Karena itu hubungan antara pelatih dan atlet harus dibangun dengan harmonis agar hubungan kekeluargaan dan kekompakan tim tidak mengalami kesenjangan dengan terbangunnya hubungan kekeluargaan dan kekompakan tim sehingga dapat meningkatkan penaikan prestasi tim.

\section{PENUTUP}

\section{A. Simpulan}

Berdasarkan hasil penelitin sebagaimana telah dipaparkan di atas maka dapat disimpulkan bahwa: 
1. Penyebab menurunnya prastasi atlet karate pada kejurnas PPLP 2017, antara lain adalah:

a. Minimnya komunikasi yang baik antara berbagai pihak yang terlibat pada persiapan kejurnas PPLP 2017. Yang mengakibatkan kurang baiknya pelayanan timbal balik antara pihak yang tekait.

b. Ada beberapa atlet yang dalam kondisi fisik yang kurang memungkin kan untuk memberikan performa tekbaiknya.

c. Keikut sertaan atlet baru untuk pertama kalinya pada kejurnas PPLP 2017 di Padang, sehingga menjadi penyebab kurangnya rasa percaya diri terhadap kemampuan yang mereka miliki.

d. Minimnya semangat dan kekompakan tim, serta kurangnya rasa kekeluargaan dalam tim.

e. Kurang maksimalnya perhatian pelatih terhadap atlet di tempat pertandingan, yang mengakibatkan para atlet yang perdana dalam mengikuti kejurnas PPLP 2017 kehilangan semangat saat pertandingan.

f. Faktor teknis Kendalanya di komunikasi karna kepala pelatih pertandingan karate itu selalu di tempatkan di Gor indoor apalagi kejurnas pplp sdh diikuti 29 provinsi jadi kepala pelatih kewalahan.

2. Penyebab meningkatnya prestasi atlet karate pada kejurnas PPLP 2018 di Aceh, antara lain adalah:

a. Bagusnya managemen pemilihan pelatih dan atlet.

b. Bagusnya pembinaan dalam program PPLP DISPORA Provinsi Sul-Sel.

c. Bagusnya managemen internal dalam kepengurusan DISPORA Sul-Sel pada tahun 2018.

d. Terpenuhnya sarana dan prasarana atlet baik, tempat latihan juga baik dan yang sesuai dengan kebutuhan atlet.

e. Terbentuknya kesiapan atlet baik dari segi fisik, tehnik dan metal dalam menghadapi kompetisi di kejurnas PPLP 2018. Tingginya motivasi dan semangat atlet dalam meraih juara.

f. Terpenuhinya segala kebutuhan gizi atlet saat pemusatan latihan.

g. Terbangunnya hubungan kekeluargaan dan kekompakan tim antara pelatih dengan atlet, antara atlet dengan atlet, serta terbangunnya komunikasi yang baik antara pengurus PPLP Sul-Sel dengan DISPORA Sul-Sel.

\section{B. Saran}

Berdasarkan hasil penelitian dan simpulan, maka dapat dikemukakan saran-saran sebagai berikut:

1. Bagi para pengurus PPLP dan DISPORA Sulawesi Selatan agar mampu berkomunikasi dengan pelatih dan atlet. Agar dalam penyedian sarana dan prasarna untuk proses latihan atlet dapat terpenuhi dengan baik. 
2. Pemilihan atlet harus dilakukan dengan melihat berbagai pertimbangan, diantaranya kesiapan atlet baik fisik maupun mental. Regenerasi atlet harus terus dilakukan agar dalam pembentukan tim tidak terjadi kesenjangan yang menyebabkan turunnya semangat atlet saat pertandingan.

3. Demi perkembangan lebih lanjut mengenai penelitian ini, disarankan kepada pembaca yang berniat untu meneliti hal yang sama atau sejenis agar kiranya meneliti lebih mendalam tentang managemen dan faktor nonteknis yang masih kurang digali oleh peneliti.

\section{DAFTAR PUSTAKA}

Atmasubrata, G. Serba Tahu Dunia Olahraga: Kumpulan Pengetahuan Umum Dunia Olahraga. Surabaya: Dafa Publishing, 2012.

Ali, A., Kowagam, H., \& Musakkir. Ensiklopedi Seni Bela Diri. Hasanuddin Universty Press, 1991.

Agustinova, D. E. Memahami Metode Penelitian Kualitatif; Teori \& Praktik. Yogyakarta: Calpulis, 2015.

Cholik, M. Implementasi Sistem Pemanduan Bakat dan Pembinaan Atlet Berbakat di Indonesia. Makalah Seminar Olahraga Nasional. Jakarta. Kantor Menpora, 1895.

Djoko pekik irianto. Dasar Kepelatihan. Yogyakarta: Fakultas Ilmu Keolahragaan Universitas Negeri Yogyakarta, 2002.

Dlis, F. Sosiologi Olahraga. Malang: Wineka Media, 2015.

Giriwijoyo, S. Sidik, D.Z. Ilmu Kesehatan Olahraga. Bandung: PT. Ramaja Rosda Karya, 2013.

----------, Ilmu Faal Olahraga (Fisiologi Olahraga) Fungsi Tubuh Manusia pada Olahraga untuk Kesehatan dan Prestasi. Bandung: PT. Ramaja Rosda Karya, 2013.

Gumanti, A. T., Yunidar., \& Syahruddin. Metode Penelitian Pendidikan. Jakarta: Mitra Wacana Media, 2016.

Harsono, Coaching dan Aspek-Aspek Psikologis Dalam Choaching. Jakarta: C.V. Tambak Kusuma, 1998.

Hanurawan, F. Metode Penelitian Kualitatif untuk Ilmu Psikologi. Depok: PT. Rajagrafindo Persada, 2016.

Harsuki. Pengantar Managemen Olahraga. Depok: PT. Rajagrafindo Persada, 2013.

Hidayat, S. Pelatihan Olahraga; Teori dan Metodologi. Yogyakarta: Graha Ilmu, 2014.

Husdarta. Psikologi Olahraga. Bandung: Alfabeta, 2011.

Lhaksana, J. Taktik dan Strategi Futsal Modern. Jakarta: Penebar Swadaya Group, 2011.

Maiyanti, S. I., Dwipurwani, O., \& Yuliana, R. Analisis Prestasi Atlet Olahraga Taekwondo Menggunakan analisis Jalur (Studi Kasus Atlet Taekwondo-In di Karigamas Sport ClubPalembang). Jurnal Penelitian Sains, 1(A), 15102 - 7, 2012.

Morgan, T. C., King, R. A., Weisz, J. R., Schopler, J. Introdution to Psychologi. Singapore: Library of Congres Catalogin-in-Publication Data, 1986.

Mylsidayu, A., Kurniawan, F. Ilmu Kepelatihan Dasar. Bandung: Alfabeta, 2015.

Pasau, A. Pertumbuhan dan Perembangan Fisik Pendidikan Jasmani, Olahraga, dan Kesehatan. Makassar: Badan Penerbit UNM, 2012. 
Rhadian, M. Karate. Bandung: PT. Indahjaya Adipratama, 2009.

Ria Lumintuarso. Perkembangan Prestasi Olahraga, 2013.

Sugiono. Metode Penelitian Kuantitatif, Kulalitatif, dan R\&D. Bandung: Alfabeta, 2017.

Sukardi. Metodologi Penelitian Pendidikan; Kompetensi dan Praktiknya. Jakarta: PT Bumi Aksara, 2014.

Wiriaatmadja, R. Metode Peneltian Tindakan Kelas. Bandung: PT Remaja Rosdakarya, 2012.

Yuliawan, I. The Way of Karate - Do 20 Sikap Mental Karateka Sejati. Jakarta: Penerbit Mudra, 2012. 